\title{
The estimated nutritive value of three common grassland species at three primary growth harvest dates following ensiling and fractionation of press-cake
}

\author{
Joseph McEniry and Padraig O’Kiely* \\ Animal \& Grassland Research and Innovation Centre, Teagasc, Grange, Dunsany, Co. Meath, Ireland \\ *e-mail: padraig.okiely@teagasc.ie
}

\begin{abstract}
In a Green Biorefinery processing green biomass one possible application for the press-cake fraction is as a feedstuff for ruminants. This study investigates the effects of ensiling and fractionation on the estimated nutritive value of three grassland species harvested at different stages of maturity. Perennial ryegrass (Lolium perenne L., var. 'Gandalf'), cocksfoot (Dactylis glomerata L., var. 'Pizza') and red clover (Trifolium pratense L., var. 'Merviot',) were grown in field plots and harvested and ensiled in laboratory silos. These silages were subsequently fractionated into presscake and press-juice fractions. Loss of soluble, fermentable organic matter during ensiling increased the relative proportions of fibre and crude protein. Fractionation resulted in the substantial reduction of herbage soluble nutrient and mineral content, increasing the fibre content and reducing digestibility and crude protein. The low energy and protein content of the press-cake fraction, especially at later harvest dates, will limit its use in ruminant diets.
\end{abstract}

Key words: Green Biorefinery, grass silage, ruminant feedstuff

\section{Introduction}

The need to develop alternatives to non-renewable fossil fuel-derived products has stimulated an interest in plant biomass to provide renewable energy, chemicals and materials. A 'Green Biorefinery' involves the sustainable processing of green biomass into a spectrum of marketable products and energy (Mandl 2010). Most technological concepts of a Green Biorefinery involve the fractionation of the cell contents (i.e. press-juice) from the plant structural framework (i.e. fibre-rich press-cake) and these separated fractions can be subjected to a series of downstream processes to recover or produce valuable products (McEniry et al. 2011). For example, lactic acid and amino acids can be extracted from the press-juice fraction (Ecker et al. 2012), while Grass (2004) described the production of thermal insulation boards from the separated press-cake fraction. Another possible application for the press-cake fraction is as a feedstuff for ruminants.

Two of the main management factors affecting herbage quality and nutritive value are herbage species and stage of maturity at harvest. Herbage harvested at an early vegetative rather than a later growth stage generally has a lower fibre content, and a higher digestibility and crude protein (CP) concentration (Buxton and O'Kiely 2003). In temperate European grasslands, perennial ryegrass (Lolium perenne L.) is commonly the preferred grass species for animal production because of its high digestibility and reduced fibre concentration (Whitehead 1995). However, other grassland species may have different physical and chemical characteristics which may offer benefits for non-agricultural uses or be more suited to specific management (e.g. response to fertiliser) or environmental (e.g. temperature, water deficit) conditions.

Preservation of herbage as silage so as to ensure year-round availability, and its subsequent fractionation, represent two major process steps in the utilization of green biomass as an industrial feedstock. However, limited information is available on the impact of these two processing steps on the nutritive value of the separated press-cake fraction. It would be expected that the process of fractionation would have a much greater deleterious effect on indices of nutritive value. Thus, the objective of this study was to quantify separately the effects of ensiling and fractionation on the estimated nutritive value of three common grassland species harvested at different stages of maturity. 


\section{Material and methods \\ Experimental plots, harvesting and ensiling}

Triplicate plots of each of two common grass species, perennial ryegrass (PRG; Lolium perenne L., var. 'Gandalf') and cocksfoot (Dactylis glomerata L., var. 'Pizza'), and one leguminous species, red clover (Trifolium pratense L., var. 'Merviot'), were grown in field plots (each $\left.20 \mathrm{~m}^{2}\right)$ at Grange $\left(53^{\circ} 52^{\prime} \mathrm{N}, 06^{\circ} 66^{\prime} \mathrm{W}\right.$ ) under an inorganic fertiliser N input of $125 \mathrm{~kg} \mathrm{~N} \mathrm{ha}^{-1}$ (except red clover which received no fertiliser N input). Separate plots were harvested at three dates (12 May [Harvest 1], 9 June [Harvest 2] and 7 July [Harvest 3]) in the primary growth in 2009 ( $n=$ 27 plots), as described previously by King et al. (2012a). On each of these dates, herbage from each plot was harvested as direct-cut material using a Haldrup forage plot harvester (J. Haldrup, Løgstor, Denmark) to an average 6 cm stubble height, passed through a precision-chop harvester (MEX VI, Pöttinger, Grieskirchen, Austria; nominal chop-length of $19 \mathrm{~mm}$ ) and a representative $6 \mathrm{~kg}$ sample from each plot was ensiled in laboratory silos (O'Kiely and Wilson 1991) for 100 days. Representative samples of each herbage pre- and post-ensiling were stored at $-18{ }^{\circ} \mathrm{C}$ prior to chemical analyses.

\section{Fractionation}

Representative $200 \mathrm{~g}$ samples of each silage (i.e. one per plot) were fractionated into press-cake and press-juice fractions, as described previously by King et al. (2012b). Briefly, $600 \mathrm{ml}$ of deionised water at $60{ }^{\circ} \mathrm{C}$, with detergent (30 g L-1; sodium dodecyl sulphate, Sigma Aldrich), was added to each representative silage sample. Sodium dodecyl sulphate is used routinely in the neutral detergent fibre assay of feedstuffs to help to dissolve pectins and plant cell components and was included to enhance the fractionation process. These 3:1 (water + detergent: silage) mixtures were maintained at $60^{\circ} \mathrm{C}$ in a water bath for 30 minutes, with thorough mixing. After 30 minutes, excess liquid was drained off using a sieve and the washing step was repeated. After the second washing step the herbage was mechanically pressed ( $4.5 \mathrm{MPa})$ using a hydraulic press to remove the press-juice fraction. The separated press-cake fractions were stored at $-18{ }^{\circ} \mathrm{C}$ prior to chemical analyses.

\section{Chemical analyses}

Representative herbage samples pre-ensiling were dried at $98{ }^{\circ} \mathrm{C}$, whilst herbage samples post-ensiling and press-cake fractions were dried at $85^{\circ} \mathrm{C}$, for $16 \mathrm{~h}$ in an oven with forced air circulation to estimate dry matter (DM) concentration. The DM concentration of the samples post-ensiling were corrected for the loss of volatiles by the equation of Porter and Murray (2001). Replicate samples were also dried at $40{ }^{\circ} \mathrm{C}$ for 48 hours before being milled (Wiley mill; $1 \mathrm{~mm}$ screen). Dried, milled samples were used for the determination of neutral detergent fibre (NDF), CP and ash, as described previously by King et al. (2012a). In vitro dry matter digestibility (DMD) was determined for the herbage samples pre- and post-ensiling by the 'two-stage rumen fluid' method of Tilley and Terry (1963). The separated press-cake fractions appeared to be deficient in N resulting in the failure of this assay. Consequently, the DMD of this material was determined using the 'pepsin-cellulase' method of Aufrère and Demarquilly (1989). The potential net energy content (i.e. feed unit for maintenance and meat production; UFV $\mathrm{kg}^{-1} \mathrm{DM}$ ) of the press-cake fractions was estimated using herbage DMD values (UFV $=0.00145773 x-0.27977273$; where $x=\operatorname{DMD}\left[\mathrm{g} \mathrm{kg}^{-1}\right]$ ) according to O'Mara (1996).

Using silage samples taken prior to drying, the $\mathrm{pH}$ was determined from an aqueous extract using a handheld $\mathrm{pH}$ meter (R 315 pH, Reagecon Diagnostics Ltd., Dublin, Ireland). Further juice was extracted for the analysis of lactic acid (LA), volatile fatty acids (i.e. acetic acid and butyric acid), ethanol and ammonia- $\mathrm{N}$ as described previously by King et al. (2012c).

\section{Statistical analysis}

Means and standard deviations (SD) were calculated for herbage chemical composition pre- and post-ensiling and for the separated press-cake fraction (Table 1). Means (SD) were also calculated for silage fermentation characteristics and this data is presented in Table 2. To investigate the true effects of harvest date and species on DMD and CP concentration, data for the herbage pre-ensiling were analysed separately as a split-plot design with harvest date as the main plot and herbage species as the subplot, and accounting for replicate blocks, using the Proc MIXED procedure of SAS, Version 9.1.2. The changes in DMD and CP concentration as a result of both ensiling and fractionation were calculated by subtracting values for (a) herbage pre-ensiling from herbage post-ensiling and (b) herbage post-ensiling from the press-cake fraction, respectively. These data were analysed as a split-plot design, according to the procedure already described. The Tukey test was used to detect the significant differences between means. 


\section{Results \\ Harvest date and species (herbage pre-ensiling)}

On average for the herbage samples pre-ensiling, DMD decreased $(p<0.01)$ with advancing harvest date, with herbage CP concentration being highest $(p<0.001)$ for the early harvest date (Harvest 1 , May 12) (Tables 1 and $3)$. Of the three herbage species investigated, red clover had a higher $(p<0.05)$ DMD than cocksfoot and a higher herbage $(p<0.001) \mathrm{CP}$ concentration than both grass species. Of the two grass species investigated, on average cocksfoot had a higher $(p<0.01)$ herbage CP concentration than the PRG.

Table 1. The effect of harvest date and species on mean (SD) herbage dry matter (DM: $\mathrm{g} \mathrm{kg}^{-1}$ ), neutral detergent fibre (NDF: $\mathrm{g} \mathrm{kg}^{-1} \mathrm{DM}$ ) and ash ( $\mathrm{g} \mathrm{kg}^{-1} \mathrm{DM}$ ) concentrations pre- and post-ensiling and on the separated presscake fraction

\begin{tabular}{lllrrr}
\hline Harvest & Species & Type & \multicolumn{1}{c}{ DM } & \multicolumn{1}{c}{ NDF } & \multicolumn{1}{c}{ Ash } \\
\hline 1 & Perennial ryegrass & Pre-ensiling & $168(5.8)$ & $496(12.5)$ & $95(3.6)$ \\
(May 12) & Perennial ryegrass & Post-ensiling & $163(7.5)$ & $512(4.8)$ & $110(5.5)$ \\
& Perennial ryegrass & Press-cake & $307(43.0)$ & $873(29.9)$ & $36(5.9)$ \\
& Cocksfoot & Pre-ensiling & $180(19.9)$ & $518(23.5)$ & $96(1.9)$ \\
& Cocksfoot & Post-ensiling & $159(2.0)$ & $535(38.7)$ & $108(2.0)$ \\
& Cocksfoot & Press-cake & $262(22.6)$ & $821(11.4)$ & $39(0.5)$ \\
& Red clover & Pre-ensiling & $142(5.1)$ & $387(21.7)$ & $101(3.0)$ \\
& Red clover & Post-ensiling & $170(2.6)$ & $405(10.5)$ & $101(1.5)$ \\
& Red clover & Press-cake & $199(24.4)$ & $644(30.5)$ & $59(3.3)$ \\
& & & & \\
(June 9) & Perennial ryegrass & Pre-ensiling & $220(8.4)$ & $609(22.3)$ & $77(2.9)$ \\
& Perennial ryegrass & Post-ensiling & $218(6.5)$ & $628(23.1)$ & $86(4.3)$ \\
& Perennial ryegrass & Press-cake & $324(9.1)$ & $919(2.1)$ & $31(2.6)$ \\
& Cocksfoot & Pre-ensiling & $221(4.4)$ & $622(49.7)$ & $92(5.1)$ \\
& Cocksfoot & Post-ensiling & $222(25.2)$ & $610(63.0)$ & $98(6.3)$ \\
& Cocksfoot & Press-cake & $324(24.4)$ & $868(49.2)$ & $35(4.3)$ \\
& Red clover & Pre-ensiling & $178(11.3)$ & $432(13.6)$ & $99(3.3)$ \\
& Red clover & Post-ensiling & $191(4.9)$ & $457(35.5)$ & $102(7.1)$ \\
& Red clover & Press-cake & $292(16.6)$ & $703(21.7)$ & $45(1.9)$ \\
& & & & \\
(July 7) & Perennial ryegrass & Pre-ensiling & $233(20.6)$ & $635(4.6)$ & $72(3.3)$ \\
& Perennial ryegrass & Post-ensiling & $234(9.4)$ & $658(37.4)$ & $73(2.4)$ \\
& Perennial ryegrass & Press-cake & $333(50.0)$ & $886(32.6)$ & $34(5.0)$ \\
& Cocksfoot & Pre-ensiling & $229(5.6)$ & $686(11.2)$ & $94(6.1)$ \\
& Cocksfoot & Post-ensiling & $223(11.1)$ & $685(35.2)$ & $104(4.1)$ \\
& Cocksfoot & Press-cake & $382(11.2)$ & $906(3.3)$ & $46(8.1)$ \\
& Red clover & Pre-ensiling & $158(6.4)$ & $466(40.9)$ & $97(7.5)$ \\
& Red clover & Post-ensiling & $167(8.4)$ & $500(80.2)$ & $100(11.6)$ \\
& Red clover & Press-cake & $288(32.5)$ & $749(43.9)$ & $45(7.8)$ \\
\hline & & & &
\end{tabular}

\section{Ensiling}

On average, the decrease in DMD as a result of ensiling did not differ ( $p>0.05)$ across the three harvest dates or the three species investigated (Table 3). Similarly, the increase in CP concentration with ensiling did not differ $(p>0.05)$ across the three harvest dates, but this increase was higher $(p<0.05)$ for the PRG compared with the cocksfoot herbage. 
Table 2. The effect of harvest date and species on mean (SD) silage fermentation characteristics $\left(\mathrm{g} \mathrm{kg}^{-1} \mathrm{DM}\right.$, except for $\mathrm{pH}$ and unless stated otherwise)

\begin{tabular}{lllrrrrr}
\hline Harvest & Species & \multicolumn{1}{c}{$\mathrm{pH}$} & \multicolumn{1}{c}{$\mathrm{LA}$} & \multicolumn{1}{c}{$\mathrm{AA}$} & \multicolumn{1}{c}{$\mathrm{BA}$} & \multicolumn{1}{c}{ EtOH } & $\mathrm{NH}_{3}-\mathrm{N}$ \\
\hline 1 & Perennial ryegrass & $4.07(0.181)$ & $93(37.7)$ & $37(11.7)$ & 0.0 & $36(5.1)$ & $58(26.4)$ \\
(May 12) & Cocksfoot & $4.37(0.185)$ & $63(10.2)$ & $43(11.7)$ & $3.8(6.58)$ & $36(12.5)$ & $72(23.5)$ \\
& Red clover & $4.15(0.138)$ & $112(38.3)$ & $22(5.8)$ & $1.1(1.82)$ & $16(2.4)$ & $61(30.9)$ \\
2 & Perennial ryegrass & $3.81(0.076)$ & $66(4.8)$ & $16(3.6)$ & 0.0 & $32(14.3)$ & $49(7.6)$ \\
(June 9) & Cocksfoot & $3.90(0.030)$ & $64(6.1)$ & $17(5.4)$ & 0.0 & $9(4.4)$ & $52(3.7)$ \\
& Red clover & $3.92(0.101)$ & $86(8.1)$ & $20(3.2)$ & 0.0 & $11(1.6)$ & $47(11.6)$ \\
3 & Perennial ryegrass & $3.52(0.081)$ & $76(4.3)$ & $23(7.2)$ & 0.0 & $27(10.3)$ & $62(11.1)$ \\
(July 7) & Cocksfoot & $4.33(0.519)$ & $21(27.3)$ & $27(9.7)$ & $7.5(1.26)$ & $19(6.6)$ & $120(57.3)$ \\
& Red clover & $4.58(0.254)$ & $35(9.1)$ & $54(21.8)$ & $3.3(5.78)$ & $40(19.7)$ & $69(15.5)$ \\
\hline
\end{tabular}

Abbreviations: LA, lactic acid; AA, acetic acid; BA, butyric acid; EtOH, ethanol; $\mathrm{NH}_{3}-\mathrm{N}$, ammonia-N $\left(\mathrm{g} \mathrm{kg}{ }^{-1} \mathrm{~N}\right)$

\section{Fractionation}

On average, the numerical decrease in DMD as a result of fractionation was lower $(p<0.01)$ for the later harvest date (Harvest 3, July 7), while no difference ( $p>0.05$ ) was observed between Harvests 1 and 2 or between the three species investigated (Tables 1 and 3 ). In contrast, the numerical decrease in CP concentration was highest $(p<0.001)$ for the Harvest 1 herbage compared with the later harvest dates. Finally, the numerical decrease in CP concentration was higher $(p<0.01)$ for the red clover compared with the two grasses. The estimated net energy content (UFV kg-1 DM) of the press-cake fractions from the Harvest 1, 2 and 3 PRG, cocksfoot and red clover were $0.67,0.48$ and $0.40,0.59,0.46$ and 0.38 , and $0.66,0.58$ and 0.49 , respectively.

Table 3. The effect of harvest date and species on herbage dry matter digestibility (DMD: $\mathrm{g} \mathrm{kg}^{-1}$ ) and crude protein concentration (CP: $\mathrm{g}$ $\mathrm{kg}^{-1} \mathrm{DM}$ ) pre-ensiling and on the changes (negative value indicates a decrease) in chemical composition as a result of ensiling (herbage post-ensiling - herbage pre-ensiling) and fractionation (press-cake fraction - herbage post-ensiling).

\begin{tabular}{|c|c|c|c|c|c|c|c|}
\hline \multirow[t]{2}{*}{ Harvest } & \multirow[t]{2}{*}{ Species } & \multicolumn{2}{|c|}{ Pre-ensiling } & \multicolumn{2}{|c|}{ Ensiling (changes) } & \multicolumn{2}{|c|}{ Fractionation (changes) } \\
\hline & & DMD & $\mathrm{CP}$ & DMD & $\mathrm{CP}$ & DMD & $\mathrm{CP}$ \\
\hline 1 & Perennial ryegrass & 785 & 141 & -1.9 & 17.0 & -133.5 & -112.7 \\
\hline \multirow[t]{2}{*}{ (May 12) } & Cocksfoot & 738 & 162 & -5.5 & 7.3 & -133.7 & -107.7 \\
\hline & Red clover & 812 & 195 & -52.8 & 7.3 & -117.2 & -113.2 \\
\hline 2 & Perennial ryegrass & 702 & 102 & -40.8 & 11.2 & -140.1 & -76.4 \\
\hline \multirow[t]{2}{*}{ (June 9) } & Cocksfoot & 653 & 120 & -18.3 & 4.9 & -128.8 & -70.5 \\
\hline & Red clover & 686 & 160 & -44.2 & 6.5 & -49.4 & -93.8 \\
\hline 3 & Perennial ryegrass & 569 & 88 & -16.6 & 12.8 & -83.8 & -58.7 \\
\hline \multirow[t]{2}{*}{ (July 7) } & Cocksfoot & 531 & 114 & -85.0 & -5.4 & -6.2 & -64.1 \\
\hline & Red clover & 611 & 159 & -35.8 & 16.3 & -45.8 & -111.3 \\
\hline \multicolumn{8}{|c|}{ Standard error of the mean } \\
\hline \multicolumn{2}{|c|}{ Main plot (Harvest) } & 19.5 & 4.3 & 17.83 & 3.34 & 14.56 & 5.20 \\
\hline \multicolumn{2}{|c|}{ Sub-plot (Species) } & 17.3 & 4.3 & 17.83 & 2.99 & 14.56 & 5.20 \\
\hline \multicolumn{2}{|c|}{ Harvest $\mathrm{x}$ species } & 30.0 & 7.5 & 30.88 & 5.17 & 25.22 & 9.00 \\
\hline \multicolumn{8}{|c|}{ Levels of significance } \\
\hline \multicolumn{2}{|l|}{ Harvest } & $* *$ & $* * *$ & NS & NS & $* *$ & *** \\
\hline \multicolumn{2}{|l|}{ Species } & $*$ & $* * *$ & NS & $*$ & NS & ** \\
\hline \multicolumn{2}{|c|}{ Harvest $x$ species } & NS & NS & NS & NS & NS & NS \\
\hline
\end{tabular}

Abbreviations: ${ }^{* * *}, p<0.001, * *, p<0.01, *, p<0.05, \mathrm{NS}$, not significant 


\section{Discussion}

The effect of ensiling and fractionation on herbage DM, NDF and ash concentrations has been presented and discussed in detail by McEniry et al. (2012). Similarly, the effect of harvest date and species on silage fermentation characteristics has been discussed in detail by King et al. (2012c). The major focus of this paper is on the effects of ensiling and fractionation on indices of nutritive value and on the suitability of the separated press-cake fraction as a feedstuff for ruminants.

\section{Harvest date and species}

The decrease in DMD and CP concentration with advancing harvest date reflects the general change in herbage chemical composition as a grass plant matures. With advancing stage of maturity, the proportion of cell wall components increases relative to the proportion of cell contents (e.g. crude protein) (Buxton 1996). The corresponding decline in herbage quality reflects the decrease in the ratio of leaf to stem tissue and the greater rate of decline in digestibility of the stem compared with the leaf due to increased lignification (Hatfield 1993).

Perennial ryegrass is commonly the preferred grass species for animal production because of its high digestibility and reduced fibre concentration (Whitehead 1995), which is apparent in the current study. The DMD of the red clover was closely related to that of the PRG and the higher CP concentration in red clover compared with the two grass species reflects the higher inherent CP concentration in legumes (Frame and Laidlaw 2011).

\section{Ensiling}

While fresh grass can be used as an industrial biomass feedstock for a Green Biorefinery, in most cases it may be necessary to preserve it as silage to ensure year round availability of a predictable quality feedstock. The general decrease in herbage DMD (-33 $\mathrm{g} \mathrm{kg}^{-1}$ on average) during ensiling in this study largely reflects the increase in NDF concentration for most silages. Small increases in the relative proportions of NDF, ash and CP occurred during ensiling as a result of a loss in organic matter during fermentation and through effluent production. For example, effluent production from the Harvest 1 PRG, cocksfoot and red clover samples was 117,50 and $287 \mathrm{~g}$ effluent $\mathrm{kg}^{-1}$ fresh material ensiled, respectively. These relatively high levels of effluent production (most evident for the PRG and red clover herbages) and poor preservation for some herbages (evident for the Harvest 3 cocksfoot herbage; where silage $\mathrm{pH}$ was 4.33 and lactic acid as a proportion of total fermentation products was 0.27$)$ contributed to the general decrease in herbage DMD. In general, however, the DMD of the Harvest 1 silages $(783,732$ and 759 $\mathrm{g} \mathrm{kg}^{-1}$ for PRG, cocksfoot and red clover, respectively) reflected excellent leafy silage and the relative changes in herbage nutritive value during ensiling were minor compared to the large negative effect of advancing harvest date on DMD.

\section{Fractionation}

The various technological options for a Green Biorefinery often involve the essential process of fractionating plant biomass into a fibre-rich press-cake and a nutrient rich press-juice. The viability of such an industrial process will depend on the range of suitable applications identified for the separated fractions (Kromus et al. 2004). The use of the press-cake fraction as a feedstuff for ruminants could be considered a relatively low-value application; nevertheless, it could be an important part of an overall biorefining process where, for example, high-value products were being produced from the press-juice fraction (e.g. lactic acid, amino acids).

Wachendorf et al. (2009) reported that fractionation reduces herbage water content and the concentration of minerals, and leads to the enrichment of fibrous constituents in the press-cake fraction. Similarly, McEniry et al. (2012) reported that $>0.55$ of the $\mathrm{N}$ and ash was removed from the press-cake fraction relative to the fresh material pre-ensiling. In the current study, the removal of a large proportion of the herbage soluble and mineral content during fractionation increased the proportion of fibrous constituents in the press-cake. Fractionation also resulted in an average 0.66 reduction in CP concentration in the press-cake fraction relative to the fresh material pre-ensiling, and this was higher for the red clover and the Harvest 1 material, reflecting the higher CP concentration in these herbages prior to fractionation. Furthermore, the failure of the 'two-stage rumen fluid' DMD assay for some of the press-cake fractions also reflects the reduction in CP concentration and a resulting deficiency in $\mathrm{N}$ for rumen microorganisms. In general, the smallest decrease in DMD and herbage CP concentration as a result of fractionation was observed for the Harvest 3 herbages and this likely reflects the relatively high fibre and low $\mathrm{CP}$ concentrations in these herbages prior to fractionation. 


\section{Press-cake fraction as a feedstuff for ruminants}

Management factors such as harvest date and species impact on the quality and nutritive value of the herbage presented for fractionation and this can subsequently influence the estimated nutritive value of the separated press-cake fraction. For example, the DMD of the press-cake fraction prepared from the Harvest 1 PRG and red clover silages ( 650 and $642 \mathrm{~g} \mathrm{~kg}^{-1}$ for PRG and red clover, respectively) could be compared with $2^{\text {nd }}$ cut grass silage ( $662 \mathrm{~g} \mathrm{~kg}^{-1}$ ) on a net energy basis $\left(0.67,0.66\right.$ and $0.68 \mathrm{UFV} \mathrm{kg}{ }^{-1} \mathrm{DM}$, respectively) (O'Mara 1996), and may have some potential for animal maintenance and low rates of production. However, this material would have to be supplemented to make up for its relatively low CP concentration (46 and $89 \mathrm{~g} \mathrm{~kg}^{-1}$ DM for the press-cake fraction from Harvest 1 PRG and red clover, respectively). With the exception of the Harvest 1 red clover, the CP concentration in all the press-cake fractions was below the requirement $(<0.08$ of diet) to support adequate rumen function and this may reduce fibre digestion in the rumen, ultimately depressing herbage DM intake (Coleman and Moore 2003).

Furthermore, the net energy content of the press-cake fraction prepared from the Harvest 1 cocksfoot and Harvest 2 red clover ( 0.59 and $0.58 \mathrm{UFV} \mathrm{kg}{ }^{-1} \mathrm{DM}$, respectively) could be compared with good quality hay ( $0.60 \mathrm{UFV}$ $\mathrm{kg}^{-1} \mathrm{DM}$ ) (Jarrige 1989). In contrast, the press-cake fraction prepared from all other later-harvested herbage had low DMD and UFV values (ranging from $444-529 \mathrm{~g} \mathrm{~kg}^{-1}$ and $0.37-0.49$ UFV kg-1 DM, respectively) similar to that reported for straw (Jarrige 1989). This suggests that any potential of the press-cake fraction as a feedstuff for ruminants is lost at later harvest dates.

In conclusion, ensiling only has a limited impact on herbage nutritive value. In contrast, fractionation resulted in a substantial increase in fibre content and a decrease in digestibility and crude protein concentration. The low energy and protein content of the resulting press-cake fraction, especially at later harvest dates, will limit its use in ruminant diets.

\section{Acknowledgements}

Funding for this research was provided under the National Development Plan, through the Research Stimulus Fund (RSF 07 557), administered by the Department of Agriculture, Food and the Marine, Ireland. The authors thank Ms. B. Weldon, farm staff and the chemical analysis laboratory staff at Teagasc Grange and Moorepark.

\section{References}

Aufrère, J. \& Demarquilly, C. 1989. Predicting organic matter digestibility of forage by two pepsin-cellulase methods. In: Proceedings of the $16^{\text {th }}$ International Grassland Congress, in October in Nice, France. Versailles, France: Association Francaise pour la Production Fourragère. p. 877-878.

Buxton, D.R. 1996. Quality-related characteristics of forages as influenced by plant environment and agronomic factors. Animal Feed Science and Technology 59: 37-49.

Buxton, D.R. \& O'Kiely, P. 2003. Preharvest plant factors affecting ensiling. In: Buxton D.R., Muck R.E. \& Harrison J.H. (eds.) Silage Science and Technology Wisconsin, USA: American Society of Agronomy. p. 199-250.

Coleman, S.W. \& Moore, J.E. 2003. Feed quality and animal performance. Field Crops Research 84: 17-29.

Ecker, J., Schaffenberger, M., Koschuh, W., Mandl, M., Böchzelt, H.G., Schnitzer, H., Harasek, M. \& Steinmüller, H. 2012. Green Biorefinery upper Austria-pilot plant operation. Separation and Purification Technology 96: 237-247.

Frame, J. \& Laidlaw, A.S. 2011. Improved Grassland Management. Wiltshire, UK: The Crowood Press Ltd. 350 p.

Grass, S. 2004. Utilisation of grass for production of fibres, protein and energy. In: Proceedings of the OECD Workshop on Biomass and Agriculture, in September in Paris, France. Paris, France: OECD Publication Service. p. 169-177.

Hatfield, R.D. 1993. Cell wall polysaccharide interaction and degradability. In: Jung, H.J., Buxton, D.R., Hatfield, R.D. \& Ralph, J. (eds.). Forage cell wall structure and digestibility. Wisconsin, USA: American Society of Agronomy. p. 285-313.

Jarrige, R. 1989. Ruminant Nutrition - recommended allowances and feed tables. London, UK: John Libbey Eurotext. 400 p.

King, C., McEniry, J., Richardson, M. \& O'Kiely, P. 2012a. Yield and chemical composition of five common grassland species in response to nitrogen fertiliser application and phenological growth stage. Acta Agriculturae Scandinavica, Section B - Soil \& Plant Science 67: 644-658.

King, C., McEniry, J., Richardson, M. \& O'Kiely, P. 2012b. The effects of hydrothermal conditioning, detergent and mechanical pressing on the isolation of the fibre-rich press-cake fraction from a range of grass silages. Biomass and Bioenergy 42: 179-188.

King, C., McEniry, J., Richardson, M. \& O'Kiely, P. 2012c. Silage fermentation characteristics of grass species grown under two nitrogen fertiliser inputs and harvested at advancing maturity in the spring growth. Grassland Science (in press).

Kromus, S., Wachter, B., Koschuh, W., Mandl, M., Krotscheck, C. \& Narodoslawsky, M. 2004. The green biorefinery Austria - development of an integrated system for green biomass utilization. Chemical and Biochemical Engineering Quarterly 18: 7-12. 
Mandl, M.G. 2010. Status of green biorefining in Europe. Biofuels, Bioproducts Biorefining 4: 268-274.

McEniry, J., Finnan, J., King, C. \& O'Kiely, P. 2012. The effect of ensiling and fractionation on the suitability for combustion of three grassland species harvested at sequential growth stages. Grass and Forage Science 67: 559-568.

McEniry J., King C. \& O'Kiely P. 2011. The grass is greener - alternative applications for Irish grass. T-Research 6: 26-27. Cited 30 July 2012. Available on the Internet: http://www.teagasc.ie/publications/2011/1002/TResearch_201106.pdf

O'Kiely, P. \& Wilson, R.K. 1991. Comparison of three silo types used to study in-silo processes. Irish Journal of Agriculture and Food Research 30: 53-60.

O'Mara, F. 1996. A net energy system for cattle and sheep. Dublin, Ireland: Department of Animal Science and Production, University College Dublin. 113 p.

Porter, M.G. \& Murray, R.S. 2001. The volatility of components of grass silage on oven drying and the inter-relationship between dry-matter content estimated by different analytical methods. Grass and Forage Science 56: 405-411.

Tilley, J.M.A. \& Terry, R.A. 1963. A two-stage technique for the in vitro digestion of forage crops. Journal of the British Grassland Association 18: 104-111.

Wachendorf, M., Richter, F., Fricke, T., Grab, R. \& Neff, R. 2009. Utilization of semi-natural grassland through integrated generation of solid fuel and biogas from biomass. I. Effects of hydrothermal conditioning and mechanical dehydration on mass flows of organic and mineral plant compounds, and nutrient balances. Grass and Forage Science 64: 132-143.

Whitehead, D.C. 1995. Grassland Nitrogen. Wallingford, UK: CAB International. 397 p. 